\title{
Primary School Teacher Performance During The Covid-19 Pandemic
}

\section{Salma Ida Nasution ${ }^{1}$, Zaka Hadikusuma Ramadan ${ }^{2}$}

1,2 Pendidikan Guru Sekolah Dasar, Universitas Islam Riau, Riau, Indonesia

\section{ART ICLE INF O}

Article history:

Received September 08, 2021

Revised September 11, 2021

Accepted October 20, 2021

Available online November 25, 2021

Kata Kunci:

Kinerja guru, covid-19, covid-19

Keywords:

Teacher performance, covid-19, covid-19

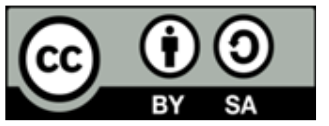

This is an open access article under the CC BY-SA license

Copyright () 2021 by Author. Published by Universitas Pendidikan Ganesha.

\section{A B S T RA K}

Dimasa pandemic covid-19 ini efektivitas kinerja guru terlihat dari kualitas kinerja guru dalam menerapkan pembelajaran daring yang melibatkan media teknologi informasi dan komunikasi. Tujuan penelitian ini menganalisis lebih dalam efektivitas kinerja guru dimasa pandemic covid-19 dalam pelaksanaan pembelajaran daring. Jenis penelitian yang digunakan adalah penelitian kualitatif. Subyek penelitian kepala sekolah, 2 guru, 2 siswa dan 2 wali murid. Instrumen penelitian yaitu lembar observasi dan pedoman wawancara. Teknik pengumpulan data yaitu wawancara dan observasi. Teknik analisis data menggunakan model Miles and Hubermen. Hasil penelitian menunjukkan bahwa efektivitas kinerja guru dimasa pandemi covid-19 ini tergolong kurang efektif. Kualitas hasil kerja guru tergolong kurang efektif karena banyaknya hambatan dalam pelaksanaan pembelajaran dimasa pandemi covid-19. Ketepatan waktu guru menurun. Inisiatif guru dimasa pandemi tergolong kurang efektif. Kemampuan guru dimasa pandemi covid-19 tergolong kurang efektif karena keterbatasan sarana prasarana, quota internet, jaringan yang tidak stabil tidak mendukung proses pembelajaran daring yang melibatkan teknologi. Komunikasi dimasa pandemi covid-19 tergolong kurang efektif karena banyaknya kendala yang menyebabkan pembelajaran tidak berlangsung sehingga tidak terjadi komunikasi yang efektif.

\begin{abstract}
A B S T R A C T
During the COVID-19 pandemic, the effectiveness of teacher performance can be seen from the quality of teacher performance in implementing online learning involving information and communication technology media. This study aims to analyze more deeply the effectiveness of teacher performance during the covid-19 pandemic in the implementation of online learning. The type of research used is qualitative research. The research subjects were principals, 2 teachers, 2 students, and 2 guardians. The research instruments are observation sheets and interview guidelines. Data collection techniques are interviews and observation. The data analysis technique used the Miles and Huberman model. The results showed that the effectiveness of teacher performance during the COVID-19 pandemic was classified as less effective. The quality of the work of teachers is classified as less effective because of the many obstacles in the implementation of learning during the COVID-19 pandemic. The teacher's punctuality decreases. Teacher initiatives during the pandemic are relatively ineffective. Teachers' ability during the COVID-19 pandemic is classified as less effective due to limited infrastructure, internet quotas, and unstable networks that do not support online learning processes involving technology. Communication during the covid-19 pandemic is classified as less effective because of the many obstacles that cause learning not to take place so that there is no effective communication.
\end{abstract}

\section{INTRODUCTION}

The Covid-19 pandemic has changed many community activities, especially in education, starting from face-to-face to online learning, causing a decrease in the quality of student learning (Dhawan, 2020; Kadafi et al., 2021; Maulana, 2021). During this COVID-19 pandemic, all levels of education are not allowed to meet face-to-face, from kindergarten to university (Ali, 2020; Hanik, 2020; Tamboto et al., 2021). Online learning uses technology media, where teachers and students cannot carry out learning in the same place. However, teachers and students can do face-to-face with the media used, such as cellphones, laptops, and others (Choi et al., 2021; Chou, 2013; Khalil, 2018). One of the efforts made by the government during this pandemic is social distancing (Jogezai et al., 2021; Karasmanaki \& Tsantopoulos, 2021; Shirish et al., 2021). 
Students and teachers cannot meet in person, this is what causes online learning (Abidah et al., 2020; Abumalloh et al., 2021). That way, there will be no social interaction between individuals during the COVID19 pandemic. In the implementation of online learning, technology media is the essential ingredient for the ongoing learning process (Ali, 2020; Teräs et al., 2020).

The success of the implementation of education is influenced by the readiness of teachers to improve the quality of their performance. Teachers are an essential factor in the success of Education (Bettencourt et al., 2011; Contreras et al., 2020). In improving the quality of learning delivery, facilities and infrastructure must be adequate so that the implementation of online learning is effective (Maican \& Cocoradă, 2021; Van Nuland et al., 2020). The success of learning is seen not only from students' achievements but also the facilities and infrastructure that must be completed (König et al., 2020; Meulenbroeks, 2020). The success of online learning is strongly influenced by the ability of teachers to use technology so that learning can be carried out anytime and anywhere through applications that are used when carrying out the learning process (Albashtawi \& Al Bataineh, 2020; Li, 2021). In order for students to be able to carry out learning, parents play an essential role in providing guidance and attention to their children regarding the use of technology in the learning process, so parents need to master technology well so that students can follow the learning process at home effectively (Kostyrka-Allchorne et al., 2017; Slovaček \& Čosić, 2020).

The success of learning can be seen from student learning competence goals which include cognitive, affective, psychomotor competencies and the ability to think and act students (Guo et al., 2020; Suryawati et al., 2020). During this pandemic, teachers also need to improve their understanding of information technology media with teacher training programs to have the skills to use computers. The benchmark of performance is seen from the results achieved, then the performance of professional teachers can improve the quality of learning, especially during the current covid-19 pandemic. Today, teachers must be professional in facing the digital era (Maican \& Cocoradă, 2021; Oktaviani \& Putra, 2021). The success of students can be seen from the performance of educators because educators play an essential role as students to lead students to the level of education (König et al., 2020; Van Nuland et al., 2020). Based on interviews with principals, teachers, parents, and students in one of the elementary schools, namely SDN Alogo Pulo Godang. At the beginning of the Covid-19 pandemic, online learning was implemented, but it did not work because of the constraints faced by both teachers, students, and parents. From the teacher's point of view, especially low-class teachers, it is difficult to implement online/online learning that involves the media. It is due to the lack of experience with online learning and the lack of understanding about the use of information technology media because the teachers who teach are old. In elementary school. Moreover, for the high class, some teachers can implement online learning using technology media. Some are not due to the difference in teacherage, which causes knowledge of information technology to vary.

From the student side, not all students have technological media such as android, so that in the implementation stage, some do not follow the learning, and some follow the learning while from the parents' side, some parents are busy with their daily work, so there is no time to supervise their children to study at home. It is what causes children to be lazy to study due to lack of attention from parents and teachers; there is no communication while online and for the principal. During the COVID-19 pandemic, the lack of assistance to educators and students has become a complaint about educators and students about the limited internet quota, facilities such as cellphones, laptops, and others. Seeing this condition, teachers and school principals changed the learning system to face-to-face with the applicable rules, such as entering only 1 hour per day, wearing masks to school, and maintaining cleanliness. The benefit of this face-to-face meeting is that all students can participate in learning even with the limited time given to the teacher. Moreover, the face-to-face process at schools was carried out before the Ministry of Education and Culture issued a circular regarding face-to-face meetings during this pandemic.

In connection with the above problems, the researchers have explored the research studies that have been done. Online learning during the COVID-19 pandemic is less effective due to the many obstacles experienced by teachers and students, such as limited internet access, limited infrastructure, and others (Arizona et al., 2020; Hutauruk \& Sidabutar, 2020). Student activity during online learning is categorized as less effective, where students are not able and ready to participate in learning because of the many obstacles actively, one of which is limited infrastructure (Napsawati, 2020; Windhiyana, 2020). During the Covid-19 pandemic, learning was less effective due to the obstacles experienced by educators and students, such as the lack of internet availability, teachers and students were not ready to operate learning involving technology media (Andriani \& Darsikin, 2016; Nurkholis, 2021). Distance learning during the COVID-19 pandemic experienced obstacles to the implementation of learning such as student readiness, internet networks, limited infrastructure, and others that made the distance learning process less effective and efficient. From the problems above, researchers are interested in analyzing the effectiveness of teacher performance during the COVID-19 pandemic in elementary schools. This study aims to analyze more deeply 
the effectiveness of teacher performance during the COVID-19 pandemic in the implementation of online learning.

\section{METHOD}

The type of research used is qualitative research. The data sources in this study were the principal, 2 teachers, 2 guardians, and 2 students. The research instruments are observation guidelines and interview sheets. Data collection techniques in this study were interviews and observation. Interviews conducted in this study formal interviews or structured interviews are questions that are asked, prepared before conducting interviews, and questions are asked based on teacher performance indicators. Data is collected when the direction and purpose of the research are clear and have obtained permission from the party providing information when conducting interviews. After the data was collected, it was analyzed using the analytical model from Miles and Huberman. The steps are as follows: 1) Data Collection: In collecting data, the researchers conducted interviews with research sources so that data obtained from interviews conducted with school principals, teachers, parents, and students to be collected. 2) Data Reduction: Reducing data is summarizing, choosing the main things, and focusing on the essential things. In this study, data reduction was carried out when researchers obtained data from school principals, teachers, parents, and students regarding teacher performance during the COVID-19 pandemic. 3) Data Presentation: After the data is reduced, the data is presented in the form of a brief description and describes the effectiveness of teacher performance during the covid-19 pandemic. So it was found how the effectiveness of teacher performance in carrying out the online learning process during the pandemic. 4) Drawing Conclusions: After the data is presented, conclusions are drawn. This conclusion is temporary, will change if it has obtained valid data.

Table 1. Research Instruments

\begin{tabular}{|c|c|c|c|c|}
\hline No & Indicator & SubIndicator & Observation & Interview \\
\hline \multirow[t]{3}{*}{1.} & Quality of work & 1. Student ability & & \\
\hline & & 2.Student understanding & $\checkmark$ & $\checkmark$ \\
\hline & & 3.Student Achievement & & \\
\hline \multirow[t]{2}{*}{2.} & Punctuality & 1. Time to come & $\checkmark$ & $\checkmark$ \\
\hline & & 2.Time to go home & & \\
\hline \multirow[t]{3}{*}{3.} & Initiative & 1. Positive thinking is better & & \\
\hline & & 2.Create creativity & $\checkmark$ & \\
\hline & & 3.Achievements & & $\checkmark$ \\
\hline \multirow[t]{3}{*}{4.} & Ability & 1. Material mastery & & \\
\hline & & 2.Assignment & $\checkmark$ & $\checkmark$ \\
\hline & & 3.Teaching Method & & \\
\hline \multirow[t]{2}{*}{5.} & Communication & 1. Delivery Quality & & \\
\hline & & 2. Mastery of class situation & $\checkmark$ & $\checkmark$ \\
\hline
\end{tabular}

\section{RESULT AND DISCUSSION}

Result

The activity of teachers during the covid-19 pandemic, especially in the learning process, was less effective because some educators did not carry out online learning during the covid-19 pandemic. While educators who carry out online learning during the covid-19 pandemic experience many obstacles in delivering learning, teachers face the limited internet quota and unstable network, as well as students, some of them do not follow the online learning process during the pandemic. covid-19 due to limited infrastructure such as cellphones, internet quotas, mainly when teachers apply to learn using the google meet application, many students do not understand the use of applications and a large number of quota uses for the google meet application so that teachers provide solutions with the WhatsApp Group application, namely sending short messages between educators With students, the teacher also sends learning videos during the COVID-19 pandemic, either in the form of learning videos or learning video links taken from YouTube.

The results of interviews with some teachers who did not implement online learning during the Covid-19 pandemic because educators and students did not understand the use of technology was seen from the students' side when the beginning of the pandemic period educators tried to implement learning. It turned out that the parents did not understand the use of applications and did not have awareness on the 
part of parents to try to learn the use of applications. So that students are unable to follow the learning process carried out by teachers online because there is no help from parents at home. Parents also pay less attention or lack of awareness in helping the process of online learning for their children in the future. So that teachers do not apply online learning for low classes during the covid-19 pandemic due to not many students being able to follow the online learning process. For high classes, some do not apply learning during the COVID-19 pandemic due to the lack of responsiveness of teachers to provide learning through technology media because teachers have seen many students who do not have supporting infrastructure for online learning, only some of them have technology media such as mobile phones. Students who have mobile media, both cellphones belonging to their parents or siblings, also experience complaints because of the lack of internet quota in carrying out online learning. The google meet application consumes a lot of internet quota, so parents do not give their cellphones because not all parents who have an excellent economic life, part of the economy is low, especially during the covid-19 pandemic. The economic condition of the guardians of students is declining, which makes it difficult for parents to pay for their children to take part in the online learning process. So that is the reason for teachers in online learning not to apply the learning process. Classes that implement online learning also do not last long. Educators have difficulty providing learning because of the many complaints from students so that the tasks given by teachers during the COVID-19 pandemic do not go well. Only some students do assignments. Some do not do assignments. So that the teacher's timeliness in carrying out the learning process is also less compelling, as seen from the learning conditions during the covid-19 pandemic.

Student learning activity is seen from several indicators: 1) students participate in carrying out tasks. Whether it is a task that is understood or not understood, students should still give assignments to educators. 2) Students ask questions if they are not understood either ask the teacher or friends. By asking, it means that students have a curious nature to understand the material with curiosity. On the other hand, if students do not have curiosity, the material given by the teacher will not be understood, or the task given by the teacher will not be carried out. 3) Participate in discussions. During this pandemic, students are not allowed to gather in groups to prevent the spread of the covid-19 virus. The solution is that teachers can give directions to their students to discuss via WhatsApp Group. 4) Participate in solving a problem discussed in a particular material, students must participate in solving problems, or there is a sense of participation in educators so that learning during the pandemic takes place effectively. 5) Students participate in finding information to solve the problems being discussed in a particular material. Students must be active and have high creativity so that problems can be solved. 6) Students can assess themselves from the results they get through the discussions that have been described previously.

Teacher initiatives during the covid-19 pandemic seem less creative. Judging by the implementation of online learning during the covid-19 pandemic, many teachers still do not understand the use of information and communication technology. Based on the information I got from the teacher's side. It was not easy to implement online learning, so that the teacher applied face-to-face learning so that the teaching and learning process continued to be carried out between educators and students because if faceto-face learning were not applied. The students would not carry out the learning process at home, thus making students lack knowledge of learning materials at school. The insight that students have does not increase, so that it makes students less understanding of learning, shallow grades. From the student side, students were lazy to carry out learning at school due to the long period of online learning that was not applied, so that students tended to play with their friends. From the parent's side, many parents do not have free time to teach their children at home, so that some parents who have a high economy give tutoring at night so that their children continue to gain knowledge during the Covid-19 pandemic.

In contrast, parents whose economy is below average then it is not provide tutoring for their children but teach their children at night, and some parents who are busy with their daily work cannot teach or teach their children at home. Online learning is learning that focuses on students, as seen from student participation in learning. If students do not take online learning, then the learning process does not take place. Online learning takes place if there is participation from students and educators. During this pandemic, only some students participate in learning, some not because of the constraints that make the learning process ineffective. The ability of teachers' performance during the COVID-19 pandemic has decreased, as can be seen from the delivery of learning materials during online learning where teachers are unable to keep up with developments in information and communication technology which causes educators to have difficulty operating technology. As a result of educators' lack of experience regarding online learning, educators cannot continue the online learning process carried out by educators and students so that material is not conveyed during online learning. From the student side, it is also seen that there is a lack of ability to operate technology such as mobile phones and the lack of students' knowledge in applying online learning that involves the use of learning applications, so it requires guidance for students to be able to operate technological media with applications used during learning, during the COVID-19 
pandemic. Parents who play an essential role in the teaching process are parents. Because parents are the closest to students at home, students need attention and guidance from parents so that the learning process can be carried out. However, on the one hand, most parents also lack knowledge of the use of cellphones, especially the lower middle class where the function of cellphones for parents is only to make calls and share news while in using learning applications, parents are still minimal in their knowledge.

Based on the interviews, the teacher used the WhatsApp Group application, Google Meet, and others. Of the two applications teachers use in delivering material, students and guardians tend to use WhatsApp Group because it is easier to use. At the same time, Google Meet parents have difficulty and educators due to lack of learning experience using technology because they are used to face-to-face in carrying out learning. So that students' ability to understand learning material is not optimal because the material delivered is only through short messages from WhatsApp Group, not to mention other disturbances that hinder the implementation of the learning process such as running out of Internet Quota, unstable network, adequate infrastructure, so that material is not conveyed to students properly. Good. Moreover, parents or their children do not have Android for the lower class, whose economy is quite good. They only use cellular phones whose function is to make calls only so that their children cannot follow the lesson so that the material presented by the teacher is not conveyed. It can be seen from one of the lower grade students that the child cannot read due to the absence of the online learning process, and the learning process at home is also less effective because students usually tend not to understand what their parents are teaching while parents are also tired of teaching their children. So that children tend not to want to learn because they enjoy playing with their friends, especially the lower classes are still relatively inclined to play. Even though from the point of view of the teacher's goal of implementing learning only to provide lessons so that students continue to carry out learning during this covid-19 pandemic. However, due to the constraints felt by educators and students, online learning was not implemented during the covid-19 pandemic, so the teacher applied face-to-face with a limited time of one hour each day so that students could still learn..

Based on observations, communication between educators, students, guardians of students, and even school principals decreased during the covid-19 pandemic because of the prohibition on gathering. The principal gave directions to maintain distance and learn with a distance system where students could only communicate through the media. Only technology such as Hp (Android), laptops. Based on the interviews I did, the communication between educators and students was lacking due to inadequate infrastructure owned by students, so there was no communication with educators. Especially for the lower class, they have difficulty using the application, so that they do not follow the lesson, and there is no communication between the teacher and the students who do not take part in the lesson. Likewise, classes that do not carry out online learning are caused by inadequate constraints. Especially those in the belowaverage economy do not have media technology (Android) because some families only have mobile phones to communicate. They cannot use learning applications. There is no communication between teachers and students because of the many obstacles during the covid-19 pandemic. Seeing the conditions that occur, the teacher carries out face-to-face learning to establish communication between students and educators. However, in face-to-face situations, communication between educators is also reduced due to the limitations of teachers in providing learning for only 1 hour each day so that communication continues but not like before the covid outbreak. -19 that hit our country.

\section{Disucssion}

The effectiveness of teacher performance during the COVID-19 pandemic is reduced. The quality of its performance has also decreased due to the changing learning model during the COVID-19 pandemic by the policies taken by many countries, including the Indonesian state, by closing all educational activities, which changed the learning system from face-to-face to online learning (Napsawati, 2020; Rigianti, 2020; Sari et al., 2021). Online learning is also defined as online learning that involves the internet network using applications such as WhatsApp Group, Google Classroom, Google Meet, Zoom, and others (Anugrahana, 2020; Sadikin \& Hamidah, 2020; Yunitasari \& Hanifah, 2020). In line with these problems, researchers see that online learning in elementary schools is not going well due to the lack of experience of teachers in the use of information and communication technology, inadequate infrastructure from teachers, students, and guardians of students, unstable internet network quality. , limited internet quota. It causes the quality of teacher performance during this pandemic not to run well, as can be seen from the delivery of material during online learning during the COVID-19 pandemic.

In line with this, students experience learning problems such as being lazy to study at home, tend to play with friends around them due to the absence of online learning so that the material presented is not conveyed to students because online learning does not take place (Napsawati, 2020; Rigianti, 2020). Seeing the many obstacles teachers face, the quality of teacher performance during the COVID-19 pandemic 
decreased because the quality of material delivery was ineffective. The effectiveness of teacher performance can be seen from the ability of teachers to achieve the success of the learning process (Andarwulan et al., 2021; Hogan \& Devi, 2019; Supriyanto et al., 2020). Teachers, students, and parents face many obstacles, so the principal directs teachers to implement face-to-face learning with applicable rules ranging from maintaining cleanliness, washing hands, wearing masks, not crowding at school, and studying time. They are limited to 1 hour per day. With the face-to-face learning process that is carried out, the teacher can only deliver the lesson briefly so that the material presented is not optimal with time constraints so that students do not understand the learning material, as can be seen from the assignments given by educators to students (Hwang et al., 2021; Ro'fah et al., 2020).

During the COVID-19 pandemic, communication was defined as delivering messages from communicators to communicants through communication tools to achieve a goal (Choi et al., 2021; Friedman \& Friedman, 2013; Gavrilenko, 2018). So that in conveying messages, the teacher must master the material that is explained and can be understood by someone so that communication can be established through questions given by students, especially during the implementation of online learning (Anitha Kumari et al., 2020; Simamora, 2020). The teacher must first examine the students what obstacles are experienced by students so that educators can choose any method of delivering material that is suitable for students so that students are active and can ask questions that they do not understand (Alchamdani et al., 2020; König et al., 2020). During the covid-19 pandemic, communication will continue if it is accompanied by complementary infrastructure. If the infrastructure is not complete, the next obstacle will occur. Therefore, educators need to improve the quality of material delivery that can provide communication between educators and students to continue without any obstacles from students and educators. Communication technology is everything related to using assistive devices in the form of applications to process and transfer information from one device to another to produce accurate information (Bergdahl et al., 2020; Friedman \& Friedman, 2013; Nikshad et al., 2021). So that teachers can communicate with the help of learning applications when carrying out online learning during the covid-19 pandemic. Digital media during the COVID-19 pandemic makes it difficult for students to develop their knowledge and abilities (Abumalloh et al., 2021; Mpungose, 2021; Onyema, 2020). When the teacher carries out online learning, students tend not to ask questions. There is no communication, and there is no purpose of communication, namely to convey information to each other, exchange information through direct face-to-face or by using indirect media such as telephone, chat, so that the message cannot be conveyed. Understood and did not get a response back that contained elements of similarity meaning.

\section{CONCLUSION}

There are five indicators for measuring the effectiveness of teacher teaching performance during the COVID-19 pandemic, namely the quality of work, timeliness, initiative, ability, and communication. None of these five aspects were influential during the learning implementation period during the COVID-19 pandemic, judging by the various obstacles that hindered the online learning process. The obstacles faced by teachers when implementing online learning are limited facilities, internet networks, lack of knowledge and understanding of educators and students in implementing online learning, no help from parents to encourage the implementation of learning involving technology media, lack of teacher creativity in creating learning, lack of awareness of school principals to assist educators and students for the online learning process at home during the covid-19 pandemic.

\section{REFERENCES}

Abidah, A., Hidaayatullaah, H. N., Simamora, R. M., Fehabutar, D., \& Mutakinati, L. (2020). The Impact of Covid-19 to Indonesian Education and Its Relation to the Philosophy of "Merdeka Belajar." Studies in Philosophy of Science and Education, 1(1), 38-49. https://doi.org/10.46627/sipose.v1i1.9.

Abumalloh, R. A., Asadi, S., Nilashi, M., Minaei-Bidgoli, B., Nayer, F. K., Samad, S., Mohd, S., \& Ibrahim, 0. (2021). The impact of coronavirus pandemic (COVID-19) on education: The role of virtual and remote laboratories in education. Technology in Society, 67(September 2020), 101728. https: //doi.org/10.1016/j.techsoc.2021.101728.

Albashtawi, A. H., \& Al Bataineh, K. B. (2020). The effectiveness of google classroom among EFL students in Jordan: An innovative teaching and learning online platform. International Journal of Emerging Technologies in Learning, 15(11), 78-88. https://doi.org/10.3991/IJET.V15I11.12865.

Alchamdani, A., Fatmasari, F., Rahmadani Anugrah, E., Putri Sari, N., Putri, F., \& Astina, A. (2020). The Impact of Covid19 Pandemic on Online Learning Process in the College at Southeast Sulawesi. Jurnal Kesehatan Lingkungan, 12(1si), 129. https://doi.org/10.20473/jkl.v12i1si.2020.129-136. 
Ali, W. (2020). Online and Remote Learning in Higher Education Institutes: A Necessity in light of COVID-19 Pandemic. Higher Education Studies, 10(3), 16-25. https://doi.org/10.5539/hes.v10n3p16.

Andarwulan, T., Al Fajri, T. A., \& Damayanti, G. (2021). Elementary teachers' readiness toward the online learning policy in the new normal era during Covid-19. International Journal of Instruction, 14(3), 771-786. https://doi.org/10.29333/iji.2021.14345a.

Andriani, N. L. Y., \& Darsikin, D. (2016). Analisis Kesulitan Siswa dalam Menyelesaikan Soal Gerak Lurus. JPFT Uurnal Pendidikan Fisika Tadulako Online), 36. https://doi.org/10.22487/j25805924.2016.v4.i3.6221.

Anitha Kumari, T., Hemalatha, C. H., Subhani Ali, M., \& Naresh, R. (2020). Survey on impact and learning's of the online courses on the present era. Procedia Computer Science, 172, 82-91. https://doi.org/10.1016/j.procs.2020.05.167.

Anugrahana, A. (2020). Hambatan, Solusi dan Harapan : Pembelajaran Daring Selama Masa Pandemi Covid19 Oleh Guru Sekolah Dasar. Scholaria: Jurnal Pendidikan Dan Kebudayaan, 10(3), 282-289. https://doi.org/10.24246/j.js.2020.v10.i3.p282-289.

Arizona, K., Abidin, Z., \& Rumansyah, R. (2020). Pembelajaran Online Berbasis Proyek Salah Satu Solusi Kegiatan Belajar Mengajar Di Tengah Pandemi Covid-19. Jurnal Ilmiah Profesi Pendidikan, 5(1). https://doi.org/10.29303/jipp.v5i1.111.

Bergdahl, N., Nouri, J., \& Fors, U. (2020). Disengagement, engagement and digital skills in technologyenhanced learning. Education and Information Technologies, 25(2), 957-983. https://doi.org/10.1007/s10639-019-09998-w.

Bettencourt, C., Velho, J. L., \& Almeida, P. A. (2011). Biology teachers' perceptions about Science-TechnologySociety (STS) education. Procedia - Social and Behavioral Sciences, 15. https://doi.org/10.1016/j.sbspro.2011.04.262.

Choi, J. J., Robb, C. A., Mifli, M., \& Zainuddin, Z. (2021). University students' perception to online class delivery methods during the COVID-19 pandemic: A focus on hospitality education in Korea and Malaysia. Journal of Hospitality, Leisure, Sport and Tourism Education, 29(August), 100336. https://doi.org/10.1016/j.jhlste.2021.100336.

Chou, P.-N. (2013). Students Perceptions Of Success In The Online Graduate-Level Classes: A Self-Directed Learning Perspective. Contemporary Issues in Education Research (CIER), 6(1), 115. https://doi.org/10.19030/cier.v6i1.7610.

Contreras, K., Arredondo, C., Díaz, C., Inostroza, M. J., \& Strickland, B. (2020). Examining differences between pre- and in-service teachers' cognition when lesson planning. System, 91. https://doi.org/10.1016/j.system.2020.102240.

Dhawan, S. (2020). Online Learning: A Panacea in the Time of COVID-19 Crisis. Journal of Educational Technology Systems, 49(1), 5-22. https://doi.org/10.1177/0047239520934018.

Friedman, L. W., \& Friedman, H. H. (2013). Using social media technologies to enhance online learning. Journal of Educators Online, 10(1). https://doi.org/10.9743/JE0.2013.1.5.

Gavrilenko, N. (2018). Online model for teaching and learning the specialized translation. Eurasia Journal of Mathematics, Science and Technology Education, 14(6), 2711-2717. https://doi.org/10.29333/ejmste/85421.

Guo, P., Saab, N., Post, L. S., \& Admiraal, W. (2020). A review of project-based learning in higher education: Student outcomes and measures. International Journal of Educational Research, 102(November 2019), 101586. https://doi.org/10.1016/j.ijer.2020.101586.

Hanik, E. U. (2020). Self directed learning berbasis literasi digital pada masa pandemi covid-19 di Madrasah $\begin{array}{lllll}\text { Ibtidaiyah. ELEMENTARY: Islamic Teacher Journal, } & 83 .\end{array}$ https://doi.org/10.21043/elementary.v8i1.7417.

Hogan, R., \& Devi, M. (2019). A synchronous pedagogy to improve online student success. International Journal of Online Pedagogy and Course Design, 9(3), 61-77. https://doi.org/10.4018/IJOPCD.2019070105.

Hutauruk, A., \& Sidabutar, R. (2020). Kendala pembelajaran daring selama masa pandemi di kalangan mahasiswa pendidikan matematika: Kajian kualiatatif deskriptif. Journal of Mathematics Education and Applied, 02(01), 45-51. https://doi.org/10.36655/sepren.v2i1.364.

Hwang, G.-J., Wang, S.-Y., \& Lai, C.-L. (2021). Effects of a social regulation-based online learning framework on students' learning achievements and behaviors in mathematics. Computers \& Education, 160. https://doi.org/10.1016/j.compedu.2020.104031.

Jogezai, N. A., Baloch, F. A., Jaffar, M., Shah, T., Khilji, G. K., \& Bashir, S. (2021). Teachers' Attitudes Towards Social Media (SM) Use in Online Learning Amid The COVID-19 Pandemic: The Effects of SM Use by Teachers and Religious Scholars During Physical Distancing. Journal Heliyon, 7(4), 1-9. https://doi.org/10.1016/j.heliyon.2021.e06781. 
Kadafi, A., Alfaiz, A., Ramli, M., Asri, D. N., \& Finayanti, J. (2021). The impact of islamic counseling intervention towards students' mindfulness and anxiety during the covid-19 pandemic. Islamic Guidance and Counseling Journal, 4(1), 55-66. https://doi.org/10.25217/igcj.v4i1.1018.

Karasmanaki, E., \& Tsantopoulos, G. (2021). Impacts of social distancing during COVID-19 pandemic on the daily life of forestry students. Children and Youth Services Review, 120(December 2020), 105781. https://doi.org/10.1016/j.childyouth.2020.105781.

Khalil, Z. M. (2018). EFL Students' Perceptions towards Using Google Docs and Google Classroom as Online Collaborative Tools in Learning Grammar. Applied Linguistics Research Journal, 2(2), 33-48. https://doi.org/10.14744/alrj.2018.47955.

König, J., Jäger-Biela, D. J., \& Glutsch, N. (2020). Adapting to online teaching during COVID-19 school closure: teacher education and teacher competence effects among early career teachers in Germany. European Journal of Teacher Education, 43(4), 608-622. https: //doi.org/10.1080/02619768.2020.1809650.

Kostyrka-Allchorne, K., Cooper, N. R., \& Simpson, A. (2017). The relationship between television exposure and children's cognition and behaviour: A systematic review. Developmental Review, 44, 19-58. https://doi.org/10.1016/j.dr.2016.12.002.

Li, B. (2021). Ready for Online? Exploring EFL Teachers' ICT Acceptance and ICT Literacy During COVID-19 in Mainland China. Journal of Educational Computing Research, 073563312110289. https: //doi.org/10.1177/07356331211028934.

Maican, M. A., \& Cocoradă, E. (2021). Online foreign language learning in higher education and its correlates during the covid-19 pandemic. Sustainability (Switzerland), 13(2), 1-21. https://doi.org/10.3390/su13020781.

Maulana, H. A. (2021). Psychological Impact of Online Learning during the COVID-19 Pandemic: A Case Study on Vocational Higher Education. Indonesian Journal of Learning Education and Counseling, 3(2), 130-139. https://doi.org/10.31960/ijolec.v3i2.833.

Meulenbroeks, R. (2020). Suddenly fully online: A case study of a blended university course moving online during the Covid-19 pandemic. Heliyon, 6(12), e05728. https://doi.org/10.1016/j.heliyon.2020.e05728.

Mpungose, C. B. (2021). Lecturers' reflections on use of Zoom video conferencing technology for e-learning at a South African university in the context of coronavirus. African Identities. https://doi.org/10.1080/14725843.2021.1902268.

Napsawati, N. (2020). Analisis Situasi Pembelajaran Ipa Fisika Dengan Metode Daring Di Tengah Wabah Covid-19. Karst: Jurnal Pendidikan Fisika Dan Terapannya, 3(1), 96-102. https: //doi.org/10.46918/karst.v3i1.546.

Nikshad, A., Aghlmandi, A., Safaralizadeh, R., Aghebati-Maleki, L., \& Warkiani, M. E. (2021). Advances of microfluidic technology in reproductive biology. Life Sciences, 265. https://doi.org/10.1016/j.lfs.2020.118767.

Nurkholis, I. (2021). Analisis Kelebihan dan Kekurangan dalam Pembelajaran Daring di SDN Pesanggrahan 01 Kota Batu Malang. PTK: Jurnal Tindakan Kelas, 2(1), 84-89. https://doi.org/10.53624/ptk.v2i1.45.

Oktaviani, N. K. W., \& Putra, M. (2021). Motivasi dan Disiplin Kerja Terhadap Kinerja Guru di Sekolah Dasar. Jurnal Imiah Pendidikan Dan Pembelajaran, 5(2), 294. https://doi.org/10.23887/jipp.v5i2.35146.

Onyema, E. M. (2020). Impact of Coronavirus Pandemic on Education. Journal of Education and Practice, 11(13), 108-121. https://doi.org/10.7176/jep/11-13-12.

Rigianti, H. A. (2020). Kendala Pembelajaran Daring Guru Sekolah Dasar Di Banjarnegara. Elementary School: Jurnal Pendidikan Dan Pembelajaran Ke-SD-An, 7(2). https://doi.org/10.31316/esjurnal.v7i2.768.

Ro'fah, R., Hanjarwati, A., \& Suprihatiningrum, J. (2020). Is Online Learning Accessible During COVID-19 Pandemic? Voices and Experiences of UIN Sunan Kalijaga Students with Disabilities. In Nadwa (Vol. 14, Issue 1). https://doi.org/10.21580/nw.2020.14.1.5672.

Sadikin, A., \& Hamidah, A. (2020). Pembelajaran Daring di Tengah Wabah Covid-19. Biodik, 6(2), 109-119. https://doi.org/10.22437/bio.v6i2.9759.

Sari, R. P., Tusyantari, N. B., \& Suswandari, M. (2021). Dampak Pembelajaran Daring Bagi Siswa Sekolah Dasar Selama Covid-19. Prima Magistra: Jurnal Ilmiah Kependidikan, 2(1), 9-15. https://doi.org/10.37478/jpm.v2i1.732.

Shirish, A., Chandra, S., \& Srivastava, S. C. (2021). Switching to online learning during COVID-19: Theorizing the role of IT mindfulness and techno eustress for facilitating productivity and creativity in student learning. International Journal of Information Management, 61(January), 102394. https://doi.org/10.1016/j.ijinfomgt.2021.102394. 
Simamora, R. M. (2020). The Challenges of Online Learning during the COVID-19 Pandemic: An Essay Analysis of Performing Arts Education Students. Studies in Learning and Teaching, 1(2), 86-103. https://doi.org/10.46627/silet.v1i2.38.

Slovaček, K. A., \& Čosić, G. (2020). The Role of Parents during the COVID19 Pandemic in Croatia. Studies in Educational Management, 8(8), 9-17. https://doi.org/10.32038/sem.2020.08.02.

Supriyanto, A., Hartini, S., Irdasari, W. N., Miftahul, A., Oktapiana, S., \& Mumpuni, S. D. (2020). Teacher professional quality: Counselling services with technology in Pandemic Covid-19. Counsellia: Jurnal Bimbingan Dan Konseling, 10(2), 176. https://doi.org/10.25273/counsellia.v10i2.7768.

Suryawati, E., Suzanti, F., Zulfarina, Putriana, A. R., \& Febrianti, L. (2020). The implementation of local environmental problem-based learning student worksheets to strengthen environmental literacy. Jurnal Pendidikan IPA Indonesia, 9(2), 169-178. https://doi.org/10.15294/jpii.v9i2.22892.

Tamboto, H., Tambingon, H. N., Lengkong, J. S. ., \& Rotty, V. N. J. (2021). The Involvement of Students' Parents in Organizing the Learning from Home at Elementary Schools in Tomohon City. Asia Pacific Journal of Management and Education, 4(1), 35-51. https://doi.org/10.32535/apjme.v4i1.1044.

Teräs, M., Suoranta, J., Teräs, H., \& Curcher, M. (2020). Post-Covid-19 Education and Education Technology 'Solutionism': a Seller's Market. Postdigital Science and Education, 2(3), 863-878. https: //doi.org/10.1007/s42438-020-00164-X

Van Nuland, S., Mandzuk, D., Tucker Petrick, K., \& Cooper, T. (2020). COVID-19 and its effects on teacher education in Ontario: a complex adaptive systems perspective. Journal of Education for Teaching, 46(4), 442-451. https://doi.org/10.1080/02607476.2020.1803050.

Windhiyana, E. (2020). Dampak Covid-19 Terhadap Kegiatan Pembelajaran Online Di Perguruan Tinggi Kristen Di Indonesia. Perspektif Ilmu Pendidikan, 34(1), 1-8. https://doi.org/10.21009/pip.341.1

Yunitasari, R., \& Hanifah, U. (2020). Pengaruh Pembelajaran Daring terhadap Minat Belajar Siswa pada Masa COVID 19. Edukatif: Jurnal Ilmu Pendidikan, 2(3), 232-243. https://doi.org/10.31004/edukatif.v2i3.142. 